\title{
Ekses Ketidaktuntasan Pembelajaran Baca Tulis Alquran terhadap Peningkatan Kuantitas Buta Huruf Arab di Kalangan Pelajar SMA/SMK Umum di Kota Bandung
}

\section{(The Excess of the Incomplete Learning of Reading and Writing of Qur'an towards the Increase in the Quantity of Arabic Illiteracy among Public High School / Vocational High School Students in Bandung)}

\section{Eni Zulaiha, B Busro}

UIN Sunan Gunung Djati Bandung, Indonesia enizulaiha@uinsgd.ac.id

DOI: $10.29240 /$ alquds.v4i2.1770

Submitted: 2019-06-30 | Revised: 2020-09-03 | Accepted: 2020-09-28

\begin{abstract}
This research aimed to find the objective condition of Al-Qur'an illiteracy among senior high school or vocational high school students in Bandung and its causes. It used a descriptive qualitative research methodwith observations and questionnaires as data collection instruments. The results showed the following: 1) the literacy rate of Al-Qur'an illiteracy among senior high school or vocational high school students in Bandung reached an average of $13 \%$ and who were not good at reading (tahsin) were $80 \%$; 2) There were many factors of less successful in learning Al-Qur'an, either internal or external factors. The conclusion showed the incomplete Baca Tulis AlQur'an (BTQ or reading and writing of Al-Qur'an) in Islamic subject learning caused by Al-Qur'an illiteracy among senior high school / vocational high school students in Bandung. Its inadequacy was due to students' low perception and motivation in the subject. Their low perception and motivation were due to unclear vision and mission of learning because BTQ learning was not the main school program, and it was also not tested at National Exam and Computer Based Test. Hence, the teacher of Islamic subject and its learning implementation were less noticed. The researchers recommend the new and varied BTQ learning designs and competent teachers to achieve religious Bandung.
\end{abstract}

Keywords: reading and writing; Al-Qur'an illiteracy; senior high school or vocational high school students in Bandung

Abstrak. Penelitian ini bertujuan menemukan kondisi obyektif tingkat buta huruf alQur'an dan faktor penghambat pembelajaran BTQ di kalangan siswa SMA / SMK umum di kota Bandung. Metode penelitian deskriptif kuantitatif dengan instrumen pengumpulan data berupa observasi dan kuesioner. Hasil penelitian menunjukkan: 1) tingkat melek huruf al-Qur'an di kalangan siswa SMA / SMK di kota Bandung 
mencapai rata-rata 13\%, dan mereka yang kurang baik dalam membaca (tabsin) adalah $80 \%$; 2) Ada hambatan kurangnya keberhasilan pembelajaran Al-Qur'an, baik dari siswa internal dan eksternal. Kesimpulan penelitian ini menemukan bahwa ketidaktuntasan pembelaran BTQ pada mata pelajaran Pendidikan Agama Islam menyebabkan lahirnya buta huruf al-Qur'an di kalangan pelajar SMA /SMK umum di kota Bandung. Ketidaktuntasan pada bidang studi tersebut karena persepsi dan motivasi siswa rendah. Rendahnya persepsi dan motivasi siswa karena tidak jelasnya visi misi pembelajarannya, ketidakjelas tersebut karena pembelajaran BTQ bukan program unggulan sekolah, tidak diujikan di UN dan UTBK sehingga pelaksanaan pembelajaran dan guru pengampunya kurang diperhatikan. Penelitian ini merekomendasikan dibutuhkan desain pembelajaran BTQ yang baru, variatif dan didukung oleh tenaga pengajar yang kompeten untuk ketercapain Kota Bandung yang agamis.

Kata Kunci: Baca Tulis; Pembelajaran Al-Quran, Pelajar Kota Bandung

\section{Pendahuluan}

Hasil Riset IIQ tahun 2018 menyimpulkan bahwa 65\% muslim di Indonesia mengalami buta aksara Al-Qur'an ${ }^{1}$. Berdasar data Susenas BPS tahun 2018, sebanyak 58,57\% muslim di Indonesia belum bisa membaca Al-Qur'an ${ }^{2}$. Jika penduduk Indonesia 250 Juta, dan 200 Juta di antaranya muslim, artinya setengahnya atau 100 juta muslim belum bisa membaca Al-Qur'an. Padahal gerakan Gemar Mengaji sebagai upaya menyelesaikan masalah ini telah dideklarasikan pertama kali oleh Menteri Agama RI, Suryadharma Ali, di Jakarta pada 26 September 2012. Kemenag mencanangkan program Gemar Mengaji bagi seluruh provinsi serta kabupaten/kota di Indonesia.

Di kota Bandung program pengentasan buta huruf al-Qur'an tidak hanya diarahkan untuk para orang tua seperti di kota kota lainya. Gerakan PBH itu diarahkan pada para pelajar. Para pelajar sebagai bagian dari masyarakat akan mengisi pembangunan di masa mendatang. Pengefektifan gerakan pengentasan buta huruf al-Qur'an bagi para pelajar diharapkan mempermudah ketercapaain pembangunan di masa mendatang ${ }^{3}$. Upaya pemerintah kota Bandung ini direspon oleh sejumlah sekolah dengan membuat program-program pengentasan buta huruf al-Qur'an dengan model dan istilah yang beragam. Akan tetapi, program-program tersebut nampak masih belum

${ }^{1}$ Muhammad Saddang, Achmad Abubakar, and Munir Munir, "Implementasi Metode Dirosa Dalam Pembelajaran Al-Qur'ān Dewan Pimpinan Daerah Wahdah Islamiyah Makassar,” Jurnal Diskursus Islam 6, no. 3 (2018): 481-500.

${ }^{2}$ Kiki Kurnia, "Gawat, 53,57 Persen Muslim Indonesia Belum Bisa Baca Alquran," Galamedia News, 2020, https://galamedia.pikiran-rakyat.com/news/pr-35554401/gawat-5357-persen-muslim-indonesia-belum-bisa-baca-alquran.

${ }^{3}$ Pemerintahan Kota Bandung, Bandung Agamis: Landasan, Pendekatan, Indikator Dan Program Aksi (Bandung: Setda Kota Bandung, 2009), 18. 
efektif, karena pada kenyataannya, jumlah angka buta huruf Al-Qur'an terus bertambah.

Diskusi tentang buta huruf al-Qur'an dan penangannya sudah banyak dilakukan para sarjana: ada tiga kecenderungan yang sudah dilakukan; 1) penelitian yang memfokuskan pada kajian keberhasilan penggunaan metode tertentu dalam upaya pemberantasan buta akasara al-Qur'an. Seperti yang dilakukan oleh Srijatun yang meneliti tentang penerapan baca tulis al-Qur'an dengan metode Iqro pada anak usia dini dan faktor-faktor yang menunjang dan menghambat pembelajaran tersebut ${ }^{4}$. M. Jamil Yusuf yang memfokuskan kajian penerapan metode Iqra' dapat dijadikan inovasi pengembangan lembaga pendidikan TK/TP Al Qur'an di berbagai daerah. ${ }^{5}$ Sadiah dan teman teman telah menunjukan metode Iqro sebagai impelemtasi model upaya pemberantasan buta huruf al-Qur'an di majlis taklim membuahkan hasil yang baik. ${ }^{6}$ Gina Giftia AD menjelaskan bahwa metode Tamam mampu meningkat kemampuan baca tulis Al-Qur'an di kalangan mahasiswa fakultas Sains dan Teknologi UIN Sunan gung Djati Bandung ${ }^{7}$. 2) Memfokuskan kajian pada pelaksanaan program pemerintah terkaitan pembealajaran alqura di masyarakat seperti yang dilakukan M. Zainuddin dkk menegaskan bahwa penyelenggaran program magrib mengaji yang dilakukan pemerintahan Pekan Baru terhadap pendidikan informal anak jalanan telah berhasil meningkat minat mereka mempelajari al-Qur'an selama dilakukan dengan pendekatan secara persuasif dan longgar ${ }^{8}$. Muhammad Nurman yang menuliskan upaya pemberantasan buta huruf al-Qur'an pada ibu-ibu majlis taklim di Desa Bayan Lombok Utara dilakukan dengan mengadakan pelatihan

${ }^{4}$ Srijatun, "Implementasi Pembelajaran Baca Tulis Al-Qur'an Dengan Metode Iqro Pada Anak Usia Dini Di RA Perwanida Slawi Kabupaten Tegal," Nadwa Jurnal Pendidikan Islam 11, no. 1 (2017).

${ }^{5}$ M Jamil Yusuf, “Metode Iqra': Kajian Inovasi Pembelajaran Al-Qur'an ,"Jurnal Edukasi: Jurnal Bimbingan Konseling 3, no. 2 (2017): 209-33.

${ }^{6}$ Unang Wahidin Sadiah, Rahendra Maya, "Impementasi Model Pembelajaran Dalam Pemberantasan Buta Hurufal-Quran Di Majelis Taklim Nurul Hikmah Kampung Situ Uncal Desa Puwasari Kecamatan Dramaga Kabupaten Bogor," Prosa PAI: Prosiding Al Hidayah Pendidikan Agama Islam 2, no. 1 (2017): 1-18.

${ }^{7}$ Gina Giftia, "Peningkatan Kemampuan Baca Tulis Huruf Al-Quran Melalui Metode Tamam Pada Mahasiswa Fakultas Sains Dan Teknologi UIN Sunan Gunung Djatu Bandung," Jurnal Istek 8, no. 7 (2014): 142-1558.

${ }^{8}$ M. Zainuddin Amir Syamsuadi, "Mhd. Rafi Yahya Pemberantsan Buta Akasara AlQuran Anak Jalanan Di Simpang Pasar Pagi Pekan Baru," Jurnal Pengabdian Masyarakat 1, no. 1 (2017). 
secara berkala dan mengasilkan kemampuan baca dan tulis yang signifikan ${ }^{9}$. Penelitian yang dilakukan Gansah Sugestian dkk yang melihat implementasi Program Magrib Mengaji di kota Bandung, penelitian ini dilakukan di mesjid alFitroh di Kota Bandung, hasil penelitian ini mengungkapkan bahwa program tersebut sudah berjalan dengan baik dan memperoleh hasil yang baik ${ }^{10}$. 3) kecenderungan kajian yang berkaitan dengan metodologi pembelajaran al-Qur'an seperti yang dilakukan Gusman yang meneliti beberapa hambatan pembelajaran BTQ menjadi penyebab buta huruf al-Qur'an pada siswa di MTS N Kedurang Bengkulu Selatan ${ }^{11}$ dan Tesis yang ditulis oleh Yoyoh Badriyah tentang Penerapan metode Fattaqun dalam kegiatan ekskul keagamaan untuk pengembangan materi PAI. Tesis ini menyimpulkan bahwa penerapan metode baru bisa menjadi inovasi pengembangan pembelajaran PAI di sekolah dalam upaya pencapaian standar akademik ${ }^{12}$. Paper ini akan melanjutkan tulisan Gusman dan Yoyoh Badriyah, yang menyatakan bahwa hambatan pembelajaran BTQ menjadi penyebab buta huruf Al-Qur'an dan penerapan metode baru bisa menjadi inovasi pengembangan pembelajaran PAI di sekolah dalam upaya pencapaian standar mutu akademik.

Ada dua persoalan yang akan dikemukakan, yakni (1) Menjelaskan penyebab kebanyakan pelajar SMA/SMK umum memiliki angka buta huruf alQur'an yang tinggi; (2) Mengungkapkan faktor internal dan eksternal yang menghambat pembelajaran BTQ pada bidang studi PAI di Sekolah SMA/SMK Umum di Kota Bandung

\section{Pembahasan}

Seperti pada namanya, pembelajaran baca tulis al-Qur'an (BTQ), mencakup pada dua hal penting, yakni membaca dan menulis Al-Qur'an. Pembelajaran membaca, merupakan pembelajaran pada dua keterampilan yang harus dikuasa pada aktifitas membaca yakni (mechanical skills) dan (comprebension skills).

\footnotetext{
${ }^{9}$ Muhammad Nurman, "Pemberantasan Buta Huruf Arab (Hijaiyah) Pada Ibu Ibu Rumah Tangga Di Desa Bayan Kecamatan Bayan Kabupaten Lombok Utara," El-Tsaqofah XVI, no. 1 (2017).

${ }^{10}$ Gansah Sugestian and Makhmud syafei Agus Fakhrudin, "Pembinaan Keagamaan Masayarakat Kota Bandung Melalui Program Magrib Mengaji; Studi Kasus Pada Mesjid Al Fitroh Kecamatan Bandung Kulon, Tarbawi Indonesian,” Journal Of Islamic Education 4, no. 2 (2017).

${ }^{11}$ Gusman, "Analis Faktor Penyebab Kurangnya Kemampuan Siswa Dalam Baca Tulis Al-Quran Di MTSN Kedurang Bengkulu Selatan,” Al-Babtsu 2, no. 2 (2017). 7

${ }^{12}$ Yoyoh Badriyah, "Penerapan Metode Fattaqun Dalam Kegiatan Ekskul Keagamaan Untuk Pengembangan Pendidikan Agama Islam” (UIN Sunan Gunung Djati Bandung, 2013).
} 
Keterampilan yang pertama meliputi pengenalan huruf dan membunyikannya hingga menghubungkan huruf ${ }^{13}$.

Berkaitan dengan ukuran kemampuan seseorang dalam membaca alQur'an, Ahmad Munir dan Sudarsono berpendapat bahwa ukuran seseorang mampu membaca Al-Qur'an dengan baik- adalah saat ia menguasai muraah al buruf wa al harakat dan muraah al kalimah wa al ayah (memiliki pengetahuan tentang huruf hijaiyah, harakat, kalimat serta ayat-ayat dan mampu melafalkan dengan baik.) ${ }^{14}$ seluruh kemampuan teknis tersebut telah diatur secara khusus dalam ilmu tajwid ${ }^{15}$.

Menurut Tu'aimah seseorang dianggap memiliki kemampuan menulis jika secara teknis ia mampu meniru ulang contoh huruf atau kata yang sudah ada, menyalin al-Qur'an setelah memperhatikan dengan seksama, tanpa melihat lagi, dan menulis huruf/kata yang diucapkan ${ }^{16}$. Menurut Budiyanto dalam Hasri, untuk mengukur kemampuan membaca dan menulis al-Qur'an digunakan sejumlah indikator yang menunjukkan tingkat atau derajat kemampuan seseorang mulai dari yang kongkrit hingga yang abstrak, mulai dari yang paling mudah hingga paling sulit, dan dari yang paling sederhana hingga paling rumit ${ }^{17}$. Dari dua pendapat ini, kiranya dapat dimengerti bahwa mereka yang tidak memiliki kemampuan membaca dan menulis dengan indikator yang sudah di tetapkan di atas, ia tergolong pada kelompok buta aksara al-Qur'an.

Meskipun berberapa ahli telah membuat batasan tentang buta huruf alQur'an, namun dalam penelitian ini, penulis menyimpulkan bahwa yang dimaksud dengan buta huruf al-Qur'an itu kondisi seseorang yang tidak mampu menyebutkan satuan huruf al-Qur'an. Jika seseorang telah mampu

\footnotetext{
${ }^{13}$ Geoffrey Broughton, Teaching English as a Foreign Language, ed. Budiyanto (England: Pincas University of London Institute of Education, 1980).

${ }^{14}$ Ahmad Munir \& Sudarsono, Ilmu Tajwid dan Seni Baca Al Qur'an (Jakarta: Rineka CIpta, 1994), 10.

${ }^{15}$ yaitu ilmu yang membahas tentang berbagai aturan atau tata cara baca Al-Qur'an dengan baik dan benar. Secara garis besar aturan tersebut meliputi pengetahuan tata cara pengucapan huruf dan karakteristiknya (makbärijul hurüf wa sifätubä), ketentuan bacaan pada hurufhuruf yang telah terstruktur dalam kata maupun kalimat (ahkeamul burüf), aturan tentang huruf yang harus dibaca panjang (abkämul mad) dan tata cara berhenti dan memulai bacaan (waqf wa ibtid $\vec{a}$ ). Ahmad An Nuri, Panduan Tabsin Tilawah Al-Qur'an \& Ilmu Tajwid (Jakarta: Pustaka al- Kautsar, 2010).

${ }^{16}$ Rusydi Aḥmad Tu’aimah, Ta'lìm Al-'Arabiyah Li Gair an-Națiquna Bihā: Manāhijubū Wa Asālibubū (Rabat: al-Munāẓamah al-Islamiyah li at- Tarbiyah wa al-'Ulūm wa aś-Śaqāâh, 1989).

${ }^{17}$ Hasri dan Nur Rahmah, "Kemampuan Baca Tulis Al-Quran Dan Korelasinya Terhadap Kemampuan Matematika Mahasiswa Prodi Tadris Matematika IAIN Palopo," AlKhawarizmi: Jurnal Matematika Dan Ilmu Pengetahuan Alam 4, no. 2 (2016): 163-72.
} 
membaca al-Qur'an tetapi masih belum tepat dalam pelafalannya tidak termasuk dalam kategori buta huruf al-Qur'an.

Dewasa ini, pendidikan Islam cenderung dimaknai sebagai sistem pendidikan dan lembaga pendidikan yang berkembang dalam peradaban Islam. Berdasarkan pengertin inilah, maka pendidikan Islam meliputi penekanan yang berbeda dengan Pendidikan Agama Islam. Karena konsep Pendidikan Agama Islam -secara praksis- lebih fokus pada konten (isi)/ muatan pendidikan itu sendiri. Sedangkan konsep pendidikan Islam diartikan sebagai konsep yang mengacu pada sistem atau model pendidikan dalam ajaran Islam. ${ }^{18}$

Pengajaran konten Agama Islam di sekolah umum pada dasarnya mengadopsi model integralistik (nadloriyyah al-wibdab) yaitu memadukan seluruh konten keagamaan dalam satu pelajaran yang disebut PAI. Pada pengimplementasinya, pembelajaran Al-Qur'an di sekolah umum, berlangsung secara bersamaan dengan pembelajaran konten keagamaan lainnya yaitu dalam pelajaran $\mathrm{PAI}^{19}$.

\section{Potret Umum Latarbelakang Tingginya Angka Buta Huruf Al-Qur'an Pelajar SMA/SMK Umum di Kota Bandung}

Kota Bandung merupakan salah satu kota di Jawa Barat yang memiliki daya tarik untuk menimba ilmu pengetahuan. Di kota ini berdiri sejumlah lembaga pendidikan dengan daya dukung sarana dan prasarana yang cukup memadai. Berbagai lembaga pendidikan mulai dari tingkat dasar sampai tingkat tinggi serta berbagai kejuruan dan bidang yang dikembangkan sangat mudah ditemukan. Sekalipun teritorial kota Bandung termasuk wilayah yang cukup sempit dibanding kabupaten/kota yang lainnnya, akan tetapi ketersediaan sarana dan prasarana pendidikan termasuk pada wilayah layak pendidikan.

Pemerintah kota Bandung memiliki perhatian yang tinggi terhadap pendidikan agama Islam (terutama pembelajaran al-Qur'an). Ini terlihat dalam kebijakan- kebijakan pembangunannya yang lebih mengarah pada pendidikan, misalnya visi dan misi Bandung bermartabat, Bandung Agamis, gerakan Tahfidz, sertifikasi tuntas baca al-Qur'an bagi pelajar dan sebagainya, pemberian beasiswa pada siswa penghafal al-Qur'an ${ }^{20}$. Hal ini tentu dapat dijadikan alasan kuat untuk membuktikan bahwa pemerintah Kota Bandung melayani pemenuhan hak pendidikan masyarakatnya.

\footnotetext{
${ }^{18}$ Ahmad Mohd Salleh, Pendidikan Islam: Falsafah, Pedagogi Dan Metodologi (Shah Alam: Fajar Bakti Sdn. Bhd, 1997).

${ }^{19}$ Muhaimin, Pengembangan Kurikulum Pendidikan Agama Islam Di Sekolah, Madrasah Dan Perguruan Tinggi (Jakarta: Grafindo Persada, 2009).

${ }^{20}$ Pemkot Bandung, Bandung Agamis: Landasan, Pendekatan, Indikator Dan Program Aksi (Bandung: Setda Kota Bandung, 2009).
} 
Data dari Dinas pendidikan, jumlah sekolah umum (SMA dan SMK) di Kota Bandung yaitu sekitar 205 sekolah $^{21}$. Dari jumlah sekolah tersebut jumlah siswa secara keseluruhan mencapai 78. 654 jiwa (hampir 80000 jiwa). Jika melihat kuantitas di atas, maka tampak jelas bahwa peminat belajar di sekolah umum di kota Bandung sangat tinggi. Sehingga Kota Bandung dijuluki kota pelajar karena penduduknya hampir disisi oleh para pelajar baik yang berdomisili di kota Bandung maupun dari luar kota Bandung. Selain itu di antara faktor, yang menjadi daya tarik orang tua utuk menyekolahkan putraputrinya di kota ini sarana dan prasarana / aksesibilitas pendidikan di kota Bandung dipandang cukup mudah dan memadai.

Seperti yang telah disinggung di atas, bahwa bahwa yang dimaksud dengan buta huruf al-Qur'an dalam penelitian ini adalah kondisi seseorang yang tidak mampu menyebutkan satuan huruf al-Qur'an saja. Untuk mendapatkan data gambaran objektif tingkat buta huruf al-Qur'an di kalangan pelajar pada sekolah umum di kota Bandung, peneliti mencoba menggunakan instrumen pengumpul data berupa angket yang disebar pada guru-guru dan siswa, wawancara dengan guru-guru PAI. Dari 20 sekolah yang kami teliti (sebagai sample) dalam penelitian ini maka diperoleh gambaran tingkat buta huruf AlQur'an pada tabel 1:

\begin{tabular}{|l|l|c|c|}
\hline No & \multicolumn{1}{|c|}{ Nama Sekolah } & $\begin{array}{c}\text { Jumlah } \\
\text { Siswa }\end{array}$ & $\begin{array}{c}\text { Persentase Buta Huruf } \\
\text { Al-Quran }\end{array}$ \\
\hline 1 & SMKN 9 & 600 & $13 \%$ \\
\hline 2 & SMKN 2 & 650 & $12 \%$ \\
\hline 3 & SMKN 10 & 800 & $10 \%$ \\
\hline 4 & SMKN 1 & 873 & $16 \%$ \\
\hline 5 & SMK Madya & 193 & $14 \%$ \\
\hline 6 & SMK Bina Warga & 262 & $13 \%$ \\
\hline 7 & SMK Vijaya Kusuma 1 & 200 & $12 \%$ \\
\hline 8 & SMK Taman Siswa 1 & 180 & $12 \%$ \\
\hline 9 & SMK Muslimin 2 & 140 & $10 \%$ \\
\hline 10 & SMK Pelita & 306 & $16 \%$ \\
\hline 11 & SMA Pasundan 2 & 443 & $17 \%$ \\
\hline 12 & SMA MUTIARA 2 & 220 & $15 \%$ \\
\hline 13 & SMA Karya & 408 & $14 \%$ \\
\hline 14 & Pembangunan 2 & & $13 \%$ \\
\hline
\end{tabular}

\footnotetext{
${ }^{21}$ Dinas Pendidikan, Data Base Dan Statistik Sekolah Umum Di Kota Bandung (Bandung: dinas pendidikan Kota Bandung, 2019).
} 


\begin{tabular}{|l|l|c|c|}
\hline 15 & SMA Al Hadi & 170 & $15 \%$ \\
\hline 16 & $\begin{array}{l}\text { SMA Negeri 26 } \\
\text { Bandung }\end{array}$ & 640 & $12 \%$ \\
\hline 17 & $\begin{array}{l}\text { SMA Negeri 24 } \\
\text { Bandung }\end{array}$ & 760 & $12 \%$ \\
\hline 18 & $\begin{array}{l}\text { SMA Negeri 10 } \\
\text { Bandung }\end{array}$ & 620 & $12 \%$ \\
\hline 19 & SMA Negeri 5 Bandung & 558 & $15 \%$ \\
\hline 20 & $\begin{array}{l}\text { SMA Negeri 25 } \\
\text { Bandung }\end{array}$ & 570 & $(265: 20)=13 \%$ \\
\hline JUMLAH
\end{tabular}

Table 1 Persentase tingkat buta huruf al-Qur'an di Sekolah di Kota Bandung

Berdasarkan tabel 1 maka dapat diketahui bahwa rata-rata siswa yang masih buta huruf al-Qur'an yaitu $13 \%$. Artinya jika jumlah siswa-siswi yang ada di kota Bandung ini jumlahnya adalah 78654 siswa, maka siswa yang masih belum mengenal simbol mushaf al-Qur'an / belum mampu membaca yaitu 10 225 siswa. Dan sisanya sekitar $20 \%$. Kemampuan siswa membaca al-Qur'an secara baik dan indah (murottal al-Quran) juga rendah. Artinya $80 \%$ siswa yang ada belum mampu membaca al-Qur'an secara baik dan indah (mampu membaca al-Qur'an secara murottal). Ini adalah angka yang cukup menghawatirkan dan perlu penangan secara serius.

Berdasarkan hasil sebaran angket, menemukan bahwa perbedaan perepsi dan orientasi sekolah juga mempengaruhi ketidakjelasan target capaian pembelajaran al-Qur'an di sekolah umum. Pada sekolah kejuruan -misalnyakarena oreintasinya pengembangan keterampilan yang bersifat vokasional, maka keahlian membaca dan menulis al-Qur'an tidak lagi menjadi target capaian utama. Akibatnya beberapa sekolah menganggap itu hal lumrah dan wajar saat siswanya tidak mampu membaca al-Qur'an, karena bagi mereka yang utama adalah capaian keterampilan kejuruan yang dikembangkan. Bahkan lebih dari itu, pembelajaran Pendidikan Agama Islam kadang diselenggarakan kurang serius, dengan alasan Pendidikan Agama Islam bukan branding sekolah dan tidak dijadikan standar kelulusan. Akhirnya lemahnya perhatian dan abainya pihak sekolah terhadap penguasaan kemampuan membaca al-Qur'an pada siswanya menyebabkan ketidakjelasan penyelenggaraan pembelajaran al-Qur'an di sekolah. Dalam konteks peneltian ini point ikut melatarbelakani tingginya angka buta huruf al-Qur'an di sekolah Umum tingkat SMA /SMK di kota Bandung .

Temuan di atas, menggakibatkan bahwa telah terjadi ketidaktuntasan penbelaran BTQ disekolah. Ketidaktuntasan yang dimaksud adalah tidak diterima dan dikuasainya semua materi BTQ dengan baik. Padahal ketuntasan pembelajaran 
BTQ dipengaruhi oleh ada tidaknya standardisasi pembelajaran al- Qur'an, baik yang terkait kurikulum, metode, kualifikasi pengajar maupun kriteria kelulusan. Sekalipun kurikulum telah menjamin materi dapat diberikan secara tuntas, namun jika tidak didukung oleh metode, pengajar yang kompeten, dan kriteria kelulusan, maka ketuntasan pembalajaran Al- Qur'an tidak akan tercapai. ${ }^{22}$

\section{Problematika Pembelajaran Baca Tulis Al-Qur'an di Kalangan Pelajar SMA/SMK Umum di Kota Bandung}

Upaya pelaksanaan pembelajaran al-Qur'an di sekolah kerap kali dihadapkan dengan kendala, baik menyangkut sarana dan prasarana fisik maupun sumber daya manusia. Berbagai jawaban dalam kuisioner menunjukkan bahwa mereka mengalami kendala teknis yang beragam sehingga terpaksa melaksanakan pembelajaran baca al-Qur'an seadanya. Pada saat yang bersamaan juga banyak sekolah yang menyatakan kesiapan untuk melaksanakan baca alQur'an dengan syarat ditunjang dan didukung oleh fasilitas pembelajaran yang memadai, termasuk dengan penguatan kapasitas (capacity building) guru PAI sendiri.

Kemampuan baca tulis al-Qur'an dapat ditunjukkan melalui prestasi belajar membaca dan menulis. Sejumlah faktor yang mempengaruhi kemampuan baca tulis al-Qur'an dapat dikelompokkan menjadi dua, faktor internal dan faktor eksternal. Faktor internal mencakup faktor fisiologis umum, panca indra, serta faktor psikologis (usia belajar, minat, kecerdasan, bakat, motivasi, kemampuan kognitif dan lainnya). Sedangkan faktor eksternal terdiri dari lingkungan (alami dan sosial) dan instrumental (kurikulum, program, dan sarana prasarana). ${ }^{23}$

Berdasarkan kajian dan analisis terhadap jawaban kuisoner, diperoleh temuan sejumlah faktor mendasar yang dipandang sebagai faktor penyebab tidak tuntasnya pembelajaran al-Qur'an di kota Bandung. Faktor-faktor ini adalah berasal dari luar diri siswa (faktor eksternal siswa) yaitu:

Pertama: Sarana belajar yang masih belum memadai secara merata. Sarana belajar al-Qur'an relatif ada, meskipun dalam jumlah yang tidak memadai. Alat pembelajaran seperti buku-buku penunjang, maupun buku-buku lain yang dapat menjadi pedoman pembelajaran baca al-Qur'an cepat di sekolah masih minim. Kurang atau bahkan tidak ada buku panduan khusus belajar cepat baca al-Qur'an yang dapat dipakai oleh para guru PAI dalam mengajarkan baca

\footnotetext{
${ }^{22}$ Budiyanto, Prinsip-Prinsip Metodologi Buku Iqra' Balai Penelitian Dan Pengembagan Sistem Pengajaran Baca Tulis Al-Qur'an LPTQ Nasional. (Yogyakarta: Team Tadarrus, 1995).318.

${ }^{23}$ Ahmad Jaeni Dkk, "Indeks Kemampuan Baca Tulis Al-Quran Mahasiswa UIN Di Indinesia Tingkat Kemampuan, Faktor Penyebab, Dan Upaya Peningkatan Șuhuf” 12, no. 2 (2019): 310.
} 
al-Qur'an kepada peserta didik. Selain itu, dari aspek media yang digunakan dalam pembelajaran masih berbasis pada buku sumber belum ada pengembangan media misalnya berbasis teknologi digital. Singkat kata, minimnya/sederhananya sarana dan prasarana (termasuk media pembelajaran) dalam pembelajaran al-Qur'an diakui sebagai salah satu faktor belum tuntasnya pembelajaran al-Qur'an di sekolah.

Kedua: Suasana lingkungan pendidikan (mileu) yang kurang mendukung terhadap pelaksanaan pembelajaran al-Qur'an di sekolah. Berdasarkan hasil observasi di sekolah, peneliti tidak menemukan sarana-sarana informasi yang mengarah pada aktivitas anak untuk membaca al-Qur'an di sekolah. Misalnya papan pajangan "Sudahkan Anda membaca al-Qur'an hari ini"?, program wajib membaca al-Qur'an sebelum belajar, gerakan sholat duha dan baca al-Qur'an ketika jam istirahat, dan sebagainya. Hal ini diperparah oleh dukungan orang tua yang rendah terhadap anaknya untuk membaca al-Qur'an. Data yang diperoleh dari angket, sebagain besar anak-anak tidak mendapatkan dorongan/ perintah dari orang tua dalam hal belajar al-Qur'an baik ketika ia di sekolah terlebih ketika berada di rumah. Misalnya keumuman orang tuanya belum pernah mendorong putra-putrinya untuk pergi ke mesjid mengikuti program magrib mengaji, pesantren atau memfasilitasi mendatangkan guru al-Qur'an ke rumahnya untuk mengajarin anak-anaknya (privat al-Qur'an ).

Ketiga: Seperti yang telah disinggung di atas, membaca dan menulis al-Qur'an adalah kemampuan teknis (technical skill), oleh karena itu dibutuhkan waktu yang lama. Pembelajaran BTQ dengan waktu yang terbatas akan menjadi kendala. Karena BTQ membutuhkan waktu untuk melatih dan mengasah. Semakin lama waktu yang dihabiskan untuk belajar al-Qur'an, semakin baik kemampuan yang akan diperoleh. Secara obyektif, ada keterbatasan waktu pembelajaran baca al-Qur'an di sekolah. Jumlah jam PAI di sekolah sekalipun ada penambahan yaitu menjadi 3 Jam, pada kenyataannya masih tetap tidak mampu mencapai standar ketuntasan yang diharapkan. Dua kemungkinan yang dirasakan oleh guru, pertama karena target pembelajaran PAI terlalu luas, kedua kompetensi dasar anak/ kemampuan awal anak dalam pembelajaran PAI masih sangat rendah; padahal menurut Ahmad Jaelani, belajar membaca dan menulis Al-Qur'an adalah kemampuan teknis (technical skill) sehingga membutuhkan waktu untuk melatih dan mengasah. Semakin lama waktu yang dihabiskan untuk belajar al-Qur'an, semakin baik kemampuan yang akan diperoleh ${ }^{24}$.

Keempat: Selain terbatas waktu, juga terbatasnya dana untuk menyelenggarakan kegiatan ini, karena sifatnya yang tidak masuk jam reguler. Keumuman sekolah tidak menyisihkan dana khusus untuk pengembangan keterampilan membaca al-Qur'an pada kegiatan ekstrakurikuler, karena memang belum mampu memberikan anggaran untuk itu. Anggaran honorarium bagi

${ }^{24}$ Ahmad Jaeni. 318. 
pembimbing al-Qur'an di sekolah, anggaran untuk pengadaan sarana belajar al-Qur'an, masih belum ada (atau walaupun ada masih belum memadai) ${ }^{25}$. Dengan kata lain, program-program pengentaasan buta huruf al-Qur'an di kalangan pelajar baik melalui program matrikulasi BTQ, Ekskul al-Qur'an, program intensif bimbingan al-Qur'an, masih belum direspon sebagai program yang serius terutama dari aspek anggaran dananya. Pada akhirya tidak sedikit guru-guru yang merasa enggan untuk melaksanakan pembelajaran al-Qur'an di luar jam PAI karena tidak dimasukan ke dalam beban kerja guru atau tidak mendapatkan honorarium yang jelas.

Kelima: Kedudukan PAI sebagai mata pelajaran yang tidak diujiankan. Regulasi ini mempengaruhi terhadap arah pembelajaran di sekolah. Tidak sedikit sekolah yang merasa terbebani oleh adanya ujian nasional. Kekhawatiran sekolah akan ketidaklulusan anak didiknya dalam mengikuti ujian nasional telah berdampak pada arah pembelajaran di sekolah yang lebih difokuskan pada pelajaran-pelajaran yang akan diujiankan. Pelajaran yang diujikan dalam ujian nasional mendapatkan prioritas utama dari pada pelajaran lainnnya yang tidak diujiankan. Nasib buruk menimpa pada pelajaran Agama Islam (PAI). Karena PAI ini dianggap sebagai pelajaran tambahan maka tidak sedikit kepala sekolah yang mengeluarkan kebijakan "aneh" yaitu mengambil jam pelajaran PAI untuk tambahan jam pelajaran yang akan diujiankan. Peristiwa ini lazim terjadi ketika menjelang detik-detik ujian nasional. Pada akhirnya, anak-anak disibukan dengan pelajaran yang akan diujikan baik pada saat UN ataupun untuk UTBK, sementara pelajaran agama (termasuk di dalamnya adalah al-Qur'an) tidak dilirik (diabaikan).

Ketujub: Metode pembelajaran yang masih monoton/kurang menarik. Pada umumnya, pembelajaran al-Qur'an yang digunakan oleh guru-guru PAI masih menggunakan metode ceramah, dengan araha materi penguasaan tajwid. Selain itu, model-model pembelajaran al-Qur'an yang digunakan masih terbatas pada model konvensional, yaitu belum mencoba menerapkan model-model pembelajaran yang kekinian yang dipandang lebih efektif dan efesien.

Kedelapan: Kompetensi guru dalam membaca al-Qur'an masih dipandang kurang. Tidak sedikit guru yang masih belum percaya diri mengajarkan keterampilan membaca al-Qur'an karena memang dirinya sendiri masih banyak kekurangan dalam membacanya. Secara teoritis, guru cukup menguasai kaidahkaidah tajwid, namun secara aplikatif masih banyak yang belum mampu

\footnotetext{
${ }^{25}$ Memang ada beberapa sekolah yang telah mampu menganggarakan dana untuk khusus penanganan buta huruf Alquran misalnya di SMAT Krida Nusantara. Untuk mengantisipasi adanya anak yang buta huruf Alquran, sekolah mencoba mendatangkan guruguru PAI secara khusu dari lembaga luar yang disatukan pada program ekstrakurikuler kepamongan Agama. Data penag SMAT Krida Nusantara.
} 
menerapkan kaidah membaca al-Qur'an secara tepat. Misalnya dari aspek pelapanan (makhorijul buruf), panjang pendek, wakof juga termasuk lagu di dalamnnnya. Rendahnya kompetensi guru dalam melantunkan bacaan AlQur'an dengan baik dan indah (tabsin al-Qur'an), dalam kenyataannya telah menjadi salah satu faktor belum berhasilnya pembelajaran al-Qur'an di sekolah $^{26}$.

Sedangkan pada faktor-internal (faktor internal yaitu semua faktor yang menyebabkan ketidakmampuan siswa dalam membaca al-Qur'an yang berasal dari siswa itu sendiri.) penyebab buta huruf al-Qur'an di kalangan pelajar di kota Bandung, yaitu:

Pertama: Persepsi siswa terhadap pentingnya belajar al-Qur'an masih belum bagus. Rata-rata siswa yang tidak bisa membaca al-Qur'an yaitu mereka yang berpandangan bahwa keterampilan membaca al-Qur'an itu tidak penting bagi kehidupan mereka. Keterampilan membaca al-Qur'an dipandang sesuatu yang tidak marketable di masyarakat. Mereka masih beranggapan bahwa keterampilan membaca al-Qur'an itu adalah miliknya sekolah madrasah bukan sekolah umum. Keterampialn membaca al-Qur'an -dalam pandangan merekatidak akan membuat dirinya menjadi percaya diri bahkan tidak akan mengantarkan masa depannnya yang cerah. Masih ada anggapan dari kalangan peserta didik bahwa belajar membaca al-Qur'an itu sulit, karena menggunakan bahasa asing, tulisan asing, dengan berbagai aturan yang harus diikuti. Ini adalah masalah tersendri. Persepsi-persepsi inilah yang dipadang oleh guru-guru PAI sebagi faktor internal siswa yang telah mewarsikan dirinya menjadi orang-orang yang buta huruf al-Qur'an.

Kedua: Motivasi Siswa yang rendah dalam membaca al-Qur'an. Rendahnya motivasi siswa ini terukur pada aktifitas belajar siswa yang sangat jarang dalam membaca al-Qur'an. Berdasarkan hasil angket tentang aktifitas belajar al-Qur'an , rata-rata siswa hanya bertemu dengan al-Qur'an (belajar AlQur'an ) yaitu ketika ada mata pelajaran PAI di sekolah (seminggu sekali). Di luar sekolah/ di luar jam belajar mereka jarang atau bahkan tidak sama sekali membuka al-Qur'an untuk belajar membaca al-Qur'an. Selain itu, rendahnya motivasi anak juga terlihat dalam minat belajar yang kurang. Peminatan siswa untuk belajar mengaji terutama di luar jam PAI sangat rendah. Berdasarkan data mereka lebih senang memilih kegiatan ekskul yang lain seperti seni, olah raga dan keterampilan lainnya daripada peminatan mengikuti pembelajaran al-Qur'an. Guru PAI mengalami kesulitan dalam mengkondisikan peserta didik untuk memiliki rasa malu jika tidak bisa membaca al-Qur'an. Sehingga banyak peserta didik yang belum bisa baca al-Qur'an tetapi cenderung enggan untuk

\footnotetext{
${ }^{26}$ Badruzzaman M Yunus dan Eni Zulaiha, Strategi pengentasan buta Huruf al-Quran di kalangan Pelajar : dari Regulasi Menuju Aksi), LP2I IAI Bunga Bangsa, Cirebon, 2019, ha 52-63
} 
mengikuti belajar. Keadaan ini tidak cukup memotivasi peserta didik untuk belajar baca al-Qur'an secara lebih giat.

Kenyataan di atas, jika dihubungkan dengan pendapat Quinn dalam Sarlito $^{27}$ yang menegaskan persepsi merupakan proses kombinasi dari sensasi yang diterima oleh organ atau hasil interprestasinya (hasil olah otak)". Pareek dalam Sobur ${ }^{28}$ mengungkapkan persepsi itu proses panca indra melakukan penerimaa, penyeleksian, pengorganisasian, mengartikan, pengujian, dan merespon sebagai gerak reaksi terhadap rangsangan yang diterima. Penjelasan ini sejalan dengan pendapat Sarlito ${ }^{29}$ mengatakan keberlangsungan persepsi terjadi saat menerima stimulus dari dunia luar yang diterima oleh organ-organ bantunya lalu masuk ke dalam otak manusia.

Dalam proses pembelajaran secara umum terdapat hubungan yang signifikan antara persepsi dan motifasi dengan tingkat keberhasilan siswa pada pembelajaran bidang studi tertentu, karena persepsi menurut pendapat para ahli di atas, dapat di pahami bahwa persepsi itu kecenderungan seseorang yang bersifat relatif, Relatif karena persepsi individu terhadap sesuatu hasilnya berbeda-beda perbedaan iotu dipengaruhi oleh persepsi yang dimilikinya. Oleh sebab itu persepsi juga akan mempengaruhi perbedaan hasil belajar setiap individu. Jika persepsi siswa pada bidang pelajaran tertentu baik maka kondisinya saat menerima, menyeleksi mengorganisasikan dari panca inderanya sebagai stimulus melakukan atau menerima pembelajaran juga akan baik.

Sedangkan motivasi belajar adalah dorongan yang timbul dari dalam diri pemain untuk mengikuti proses perkuliahan dengan sungguh-sungguh. Lebih lanjut Sofyan, Nurholis dan Hendra mengemukakan bahwa motivasi belajar merupakan suatu dorongan yang terjadi dalam diri individu untuk senantiasa meningkatkan kualitas tertentu dengan sebaik-baiknya atau lebih dari yang biasa dilakukan $^{30}$. Kemudian Baharudin dan Esa Nur Wahyuni, mengemukakan bahwa "Motivasi belajar adalah proses aktualisasi sumber penggerak dan pendorong tingkah laku individu memenuhi kebutuhan untuk mencapai tujuan tertentu"31.

Motivasi belajar sebagai daya dorong yang memungkinkan seseorang berhasil mencapai apa yang dicita -citakan. Seseorang yang memiliki motivasi

${ }^{27}$ Sarlito Wirawan Sarwono, Teori Teori Psikologi (Jakarta: Raja Garafindo, 2012), 93.

${ }^{28}$ Alex Sobur, Psikologi Umum (Bandung: Pusataka Setia, 2003). 446

${ }^{29}$ Sarwono, Teori Teori Psikologi, 86.

${ }^{30}$ Hendra Sofyan, Nurholis, "Strategi Pembelajaran Al-Qur'an Di Ma'had AlJami'ah UIN Ar-Raniry Banda Aceh," EDUKASI Jurnal Penelitian Pendidikan Agama Dan Keagamaan., 2019.

${ }^{31}$ Esa Nur Wahyuni dan Baharudin, Teori Belajar \& Pembelajaran (Yogyakarta: Ar Ruzz Media Group, 2008). 
belajar tinggi cenderung untuk selalu berusaha mencapai apa yang diinginkan walaupun mengalami hambatan dan kesulitan dalam meraihnya. Persepsi merupakan kecenderungan seseorang terhadap sesuatu dalam ranah relatif, artinya persepsi individu terhadap sesuatu akan muncul secara berbeda berdasarkan persepsinya. Persepsi mempengaruhi hasil belajar setiap individu.

Motivasi belajar merupakan faktor yang berasal dari dalam diri siswa untuk mengikuti pembelajaran dan berpengaruh terhadap hasil belajar. Motivasi intrinsik merupakan faktor utama yang berperan dalam menciptakan hasil belajar yang baik. Oleh karena itu, kiranya dapat dipahami bahwa hal yang melatarbelakangi tingginya angka butu huruf Al-Qur'an dari sisi internal di kalangan siswa SMA/SMK umum di kota Bandung adalah rendahnya persepsi dan motoivasi mereka terhadap pembelaran BTQ di sekolahnya.

Data yang menggambarkan dua faktor di atas secara tidak langsung juga menegaskan bahwa persoalan tingkat kemampuan baca tulis Al-Qur'an dipengaruhi oleh ketidaktuntasan dalam menempuh pembelajaran al- Qur'an. Siswa yang pernah mengenyam pengajaran al-Qur'an di masa sebelumnya (SD dan SMP) sebenarnya juga telah menempuh pembelajaran al-Qur'an dalam waktu yang lebih lama. Misalnya, sebelum masuk Madrasah Diniyah, mereka telah menempuh pendidikan al-Qur'an TKA/TPA dan dinyatakan lulus. Dengan masa tempuh pembelajaran yang cukup panjang di lembaga yang memang memiliki core dalam pengajaran Al-Qur'an, maka tingkat ketuntasannya jauh lebih baik. Berbeda dengan siswa yang menempuh pembelajaran al-Qur'an di dalam sekolah, ketuntasannya dalam belajar al-Qur'an terlihat rendah.

Masih besarnya persentase siswa SMA/SMK di kota Bandung dengan tingkat kemampuan baca tulis Al-Qur'an yang rendah, pada giliran tertentu mengakibatkan UIN dan Perguruan Tinggi Islam pada umumnya, menanggung beban problem BTQ yang serius, baik di fakultas agama maupun non agama.

\section{Kesimpulan}

Bedasarkan data yang penulis peroleh melalui angket yang disebar dan juga wawancara, menunjukan bahwa ketidaktuntasan pembelajaran BTQ yang digabung pada pembelajaran PAI adalah faktor yang melatarbelakangi tingginya angka buta aksara al-Qur'an di kalangan pelajar SMA/ SMK di Kota Bandung. Kenyataan ini juga di sisi lain diakibatkan karena faktor internal rendahnya persepsi dan motivasi siswa pada pelajaran ini, karena ia tidak menjadi pelajaran unggulan yang diujikan di UN dan UTBK. Pada aspek eksternal penyelenggaran pembelaran BTQ belum memperoleh perhatian khusus baik dari sisi desain pembelajaran, waktu, kejelasan visi misi, dan tenaga pengajar yang kurang kompeten. 


\section{Bibliografi}

Ahmad Jaeni, Dkk. "Indeks Kemampuan Baca Tulis Ai-Quran Mahasiswa Uin Di Indinesia Tingkat Kemampuan, Faktor Penyebab, Dan Upaya Peningkatan Șuhuf' 12, no. 2 (2019): 310.

An Nuri, Ahmad. Panduan Tabsin Tilawah Al- Qur'an \& Ilmu Tajwid. Jakarta: Pustaka al- Kautsar, 2010.

Badriyah, Yoyoh. "Penerapan Metode Fattaqun Dalam Kegiatan Ekskul Keagamaan Untuk Pengembangan Pendidikan Agama Islam." UIN Sunan Gunung Djati Bandung, 2013.

Baharudin, Esa Nur Wahyuni. Teori Belajar \& Pembelajaran. Yogyakarta: Ar Ruzz Media Group, 2008.

Bandung, Pemerintahan Kota. Bandung Agamis: Landasan, Pendekatan, Indikator Dan Program Aksi. Bandung: Setda Kota Bandung, 2009.

Bandung, Pemkot. Bandung Agamis: Landasan, Pendekatan, Indikator Dan Program Aksi. Bandung: Setda Kota Bandung, 2009.

Broughton, Geoffrey. Teaching English as a Foreign Language. Edited by Budiyanto. England: Pincas University of London Institute of Education, 1980.

Budiyanto. Prinsip-Prinsip Metodologi Buku Iqra' Balai Penelitian Dan Pengembagan

Sistem Pengajaran Baca Tulis Al-Qur'an LPTQ Nasional. Yogyakarta:

Team Tadarrus, 1995.

Giftia, Gina. "Peningkatan Kemampuan Baca Tulis Huruf Al-Quran Melalui Metode Tamam Pada Mahasiswa Fakultas Sains Dan Teknologi UIN Sunan Gunung Djatu Bandung." Jurnal Istek 8, no. 7 (2014): 142-1558.

Gusman. "Analis Faktor Penyebab Kurangnya Kemampuan Siswa Dalam Baca Tulis Al-Quran Di MTSN Kedurang Bengkulu Selatan.” Al-Babtsu 2, no. 2 (2017).

Harsanto, Ratno. Pengelolaan Kelas Yang Dinamis. Yogyakarta: Kanisius, 2007.

Kurnia, Kiki. "Gawat, 53,57 Persen Muslim Indonesia Belum Bisa Baca AlQur'an ."Galamedia News, 2020. https://galamedia.pikiranrakyat.com/news/pr-35554401/gawat-53-57-persen-muslim-indonesiabelum-bisa-baca-al-Qur'an .

Muhaimin. Pengembangan Kurikulum Pendidikan Agama Islam Di Sekolah, Madrasah Dan Perguruan Tinggi. Jakarta: Grafindo Persada, 2009.

Nurman, Muhammad. "Pemberantasan Buta Huruf Arab (Hijaiyah) Pada Ibu Ibu Rumah Tangga Di Desa Bayan Kecamatan Bayan Kabupaten Lombok Utara." El-Tsaqofah XVI, no. 1 (2017).

Pendidikan, Dinas. Data Base Dan Statistik Sekolah Umum Di Kota Bandung. Bandung: dinas pendidikan Kota Bandung, 2019.

Rahmah, Hasri dan Nur. "Kemampuan Baca Tulis Al-Quran Dan Korelasinya Terhadap Kemampuan Matematika Mahasiswa Prodi Tadris Matematika 
IAIN Palopo." Al-Khawarizmi: Jurnal Matematika Dan Ilmu Pengetahuan Alam 4, no. 2 (2016): 163-72.

Saddang, Muhammad, Achmad Abubakar, and Munir Munir. "Implementasi Metode Dirosa Dalam Pembelajaran Al-Qur'ān Dewan Pimpinan Daerah Wahdah Islamiyah Makassar." Jurnal Diskursus Islam 6, no. 3 (2018): 481-500.

Sadiah, Rahendra Maya, Unang Wahidin. "Impementasi Model Pembelajaran Dalam Pemberantasan Buta Hurufal-Quran Di Majelis Taklim Nurul Hikmah Kampung Situ Uncal Desa Puwasari Kecamatan Dramaga Kabupaten Bogor." Prosa PAI: Prosiding Al Hidayah Pendidikan Agama Islam 2, no. 1 (2017): 1-18.

Salleh, Ahmad Mohd. Pendidikan Islam: Falsafah, Pedagogi Dan Metodologi. Shah Alam: Fajar Bakti Sdn. Bhd, 1997.

Sarwono, Sarlito Wirawan. Teori Teori Psikologi. Jakarta: Raja Garafindo, 2012. Sobur, Alex. Psikologi Umum. Bandung: Pusataka Setia, 2003.

Sofyan, Nurholis, Hendra. "Strategi Pembelajaran Al-Qur'an Di Ma'had AlJami'ah UIN Ar-Raniry Banda Aceh." EDUKASI Jurnal Penelitian Pendidikan Agama Dan Keagamaan., 2019.

Srijatun. "Implementasi Pembelajaran Baca Tulis Al-Qur'an Dengan Metode Iqro Pada Anak Usia Dini Di RA Perwanida Slawi Kabupaten Tegal." Nadwa Jurnal Pendidikan Islam 11, no. 1 (2017).

Sudarsono, Ahmad Munir \&. Ilmu Tajwid Dan Seni Baca Al Qur'an. Jakarta: Rineka CIpta, 1994.

Sugestian, Gansah, and Makhmud syafei Agus Fakhrudin. "Pembinaan Keagamaan Masayarakat Kota Bandung Melalui Program Magrib Mengaji; Studi Kasus Pada Mesjid Al Fitroh Kecamatan Bandung Kulon, Tarbawi Indonesian." Journal Of Islamic Education 4, no. 2 (2017).

Syamsuadi, M. Zainuddin Amir. "Mhd. Rafi Yahya Pemberantsan Buta Akasara

Al-Quran Anak Jalanan Di Simpang Pasar Pagi Pekan Baru." Jurnal Pengabdian Masyarakat 1, no. 1 (2017).

Tu'aimah, Rusydi Aḥmad. Ta'lim Al-Arabiyah Li Gair an-Natiqina Bibāa: Manābijubū Wa Asālibubū. Rabat: al-Munāzamah al-Islamiyah li atTarbiyah wa al-'Ulūm wa aś-Śaqāfah, 1989.

Yusuf, M Jamil. "Metode Iqra': Kajian Inovasi Pembelajaran Al-Qur'an ." Jurnal Edukasi: Jurnal Bimbingan Konseling 3, no. 2 (2017): 209-33. 